\title{
Kinetics Study of Photocatalytic Activity of Flame-Made Unloaded and Fe-Loaded $\mathrm{CeO}_{2}$ Nanoparticles
}

\author{
D. Channei, ${ }^{1}$ B. Inceesungvorn, ${ }^{1}$ N. Wetchakun, ${ }^{2}$ and S. Phanichphant ${ }^{3}$ \\ ${ }^{1}$ Department of Chemistry, Faculty of Science, Chiang Mai University, Chiang Mai 50200, Thailand \\ ${ }^{2}$ Department of Physics and Materials Science, Faculty of Science, Chiang Mai University, Chiang Mai 50200, Thailand \\ ${ }^{3}$ Materials Science Research Center, Faculty of Science, Chiang Mai University, Chiang Mai 50200, Thailand
}

Correspondence should be addressed to S. Phanichphant; sphanichphant@yahoo.com

Received 8 June 2013; Accepted 4 October 2013

Academic Editor: Jiaguo Yu

Copyright (C) 2013 D. Channei et al. This is an open access article distributed under the Creative Commons Attribution License, which permits unrestricted use, distribution, and reproduction in any medium, provided the original work is properly cited.

\begin{abstract}
Unloaded $\mathrm{CeO}_{2}$ and nominal 0.50, 1.00, 1.50, 2.00, 5.00, and $10.00 \mathrm{~mol} \%$ Fe-loaded $\mathrm{CeO}_{2}$ nanoparticles were synthesized by flame spray pyrolysis (FSP). The samples were characterized to obtain structure-activity relation by X-ray diffraction (XRD), highresolution transmission electron microscopy (HRTEM), Brunauer, Emmett, and Teller (BET) nitrogen adsorption, X-ray photoelectron spectroscopy (XPS), and UV-visible diffuse reflectance spectrophotometry (UV-vis DRS). XRD results indicated that phase structures of Fe-loaded $\mathrm{CeO}_{2}$ nanoparticles were the mixture of $\mathrm{CeO}_{2}$ and $\mathrm{Fe}_{2} \mathrm{O}_{3}$ phases at high iron loading concentrations. HRTEM images showed the significant change in morphology from cubic to almost-spherical shape observed at high iron loading concentration. Increased specific surface area with increasing iron content was also observed. The results from UVvisible reflectance spectra clearly showed the shift of absorption edge towards longer visible region upon loading $\mathrm{CeO}_{2}$ with iron. Photocatalytic studies showed that Fe-loaded $\mathrm{CeO}_{2}$ sample exhibited higher activity than unloaded $\mathrm{CeO}_{2}$, with optimal 2.00 mol\% of iron loading concentration being the most active catalyst. Results from XPS analysis suggested that iron in the Fe ${ }^{3+}$ state might be an active species responsible for enhanced photocatalytic activities observed in this study.
\end{abstract}

\section{Introduction}

Organic compounds from industries are one of the major causes of water pollution [1]. Various strategies have been employed to remove these toxic compounds $[2,3]$. One of the most interesting approaches is heterogeneous photocatalysis because the process is based on the use of solar energy, which is clean and abundant in nature $[4,5]$. In the recent years, cerium dioxide $\left(\mathrm{CeO}_{2}\right.$ or ceria) has received considerable attention because this material shows promising applications in solid oxide fuel cells [6], environmental catalysis [7, 8], redox catalysis [9], and wet catalytic oxidation of organic pollutants [10]. However, the band gap of $\mathrm{CeO}_{2}(3.22 \mathrm{eV})$ has limited the activation of solar energy; only UV light can be applied to generate electron-hole pairs at the beginning of photocatalytic processes. Thus, it is necessary to extend the absorbance of $\mathrm{CeO}_{2}$ into visible region and reduce the electron-hole pairs recombination [11,12]. There are many methods to modify light absorption properties of $\mathrm{CeO}_{2}$, such as metal doping [13, 14], surface sensitization [15], and coupling with semiconductor that has smaller band gap [16]. Recently, transition metal doping/loading has been widely used to enhance the light absorption of $\mathrm{CeO}_{2}[17,18]$. It has been reported in many works of literature that the metal ions of Pt [19], Ag [20], Fe [21], Mn [22], Co [23], Ni [24], and $\mathrm{Zn}[25]$ in $\mathrm{CeO}_{2}$ could improve $\mathrm{CeO}_{2}$ photocatalytic activity towards the visible-light region. Among these metals, Fe has been considered as a candidate owing to its special Fenton reaction of iron. The Fenton process can improve the photocatalytic activity by producing the hydroxyl radicals $\left(\mathrm{OH}^{*}\right)$ which are very powerful oxidizer in photocatalytic process [26]. There are many methods to prepare unloaded $\mathrm{CeO}_{2}$ and Fe-doped/-loaded $\mathrm{CeO}_{2}$ nanoparticles such as sol-gel [27], sonochemical [28], homogeneous precipitation [29], hydrothermal [30], microemulsions [31], surfactant-assisted precipitation [32], and flame spray pyrolysis (FSP) methods [33]. 
Among them, the latter one is a promising approach because FSP can produce the nanoparticle products with particle size in the range of $1-200 \mathrm{~nm}$ at high production rates up to $250 \mathrm{~g} / \mathrm{h}$ in one step [34]. Other advantages are the ability to dissolve the precursor directly in the fuel and the simplicity of introduction of the precursor into the hot flame zone. In addition, the process of loading/doping metal oxide with metals can easily be done by adding dopant in the precursor solution $[35,36]$. In the present work, unloaded $\mathrm{CeO}_{2}$ and Fe-loaded $\mathrm{CeO}_{2}$ nanoparticles were directly synthesized by FSP method. The formic acid and oxalic acid were chosen as model organic pollutants for photocatalytic study under visible-light irradiation.

\section{Experimental}

2.1. Preparation of Powders. The precursor solutions for FSP consisted of cerium nitrate hexahydrate (Sigma-Aldrich, 99.99 wt\%) and iron acetyl acetonate (Sigma-Aldrich, $97 \mathrm{wt} \%)$. The cerium precursor was dissolved in absolute ethanol (Scharlau, 98\%) to obtain a $0.50 \mathrm{M}$ concentration. Amounts of Fe loading concentration were varied as 0.50 , $1.00,1.50,2.00,5.00$, and $10.00 \mathrm{~mol} \%$ in order to prepare Feloaded $\mathrm{CeO}_{2}$ samples. The precursor mixtures were fed into the center of flame by syringe pump with a rate of $5 \mathrm{~mL} / \mathrm{min}$ and dispersed by $5 \mathrm{~L} / \mathrm{min}$ oxygen according to the previous report [37]. Then, the liquid precursor was dispersed quickly in an upward direction by gas stream and ignited by premixed oxygen/methane flame. The gas flow rates of oxygen and methane-supporting flame were set as constant rates of 1.19 and $2.46 \mathrm{~L} / \mathrm{min}$, respectively. After evaporation and combustion of liquid precursor droplet, nanoparticle products were collected on a glass microfiber filter papers (Whatmann $\mathrm{GF} / \mathrm{A}, 25.7 \mathrm{~cm}$ in diameter) with a vacuum pump controller.

2.2. Characterization of Nanoparticles. The phase and crystallinity of the synthesized samples were analyzed by Xray powder diffraction (XRD; Philips X'Pert MPD; CuK $\alpha$ radiation). The most intense peak corresponding to (111) plane was chosen to calculate the crystallite sizes $(D)$ using Scherrer equation as follow:

$$
D=\frac{k \lambda}{\beta \cos \theta},
$$

where $k$ is a constant equal to $0.89, \lambda$ is the $\mathrm{X}$-ray wavelength equal to $0.154 \mathrm{~nm}, \beta$ is the full width at half-maximum (FWHM), and $\theta$ is the half-diffraction angle [38]. The chemical composition and oxidation state of material were studied by X-ray photoelectron spectroscopy (XPS) using Mg X-ray source $(\mathrm{MgK} \alpha$, Kratos Axis Ultra DLD). The binding energy of the adventitious carbon (C $1 \mathrm{~s}$ ) line at $285 \mathrm{eV}$ was used for calibration, and the position of other peaks was corrected according to the position of the $\mathrm{C} 1 \mathrm{~s}$ signal. Highresolution transmission electron microscopy (HRTEM, JEOL JEM-2010) was employed to determine the morphology of prepared samples. The mean particle size and specific surface area (SSA) were investigated using the Brunauer, Emmett,

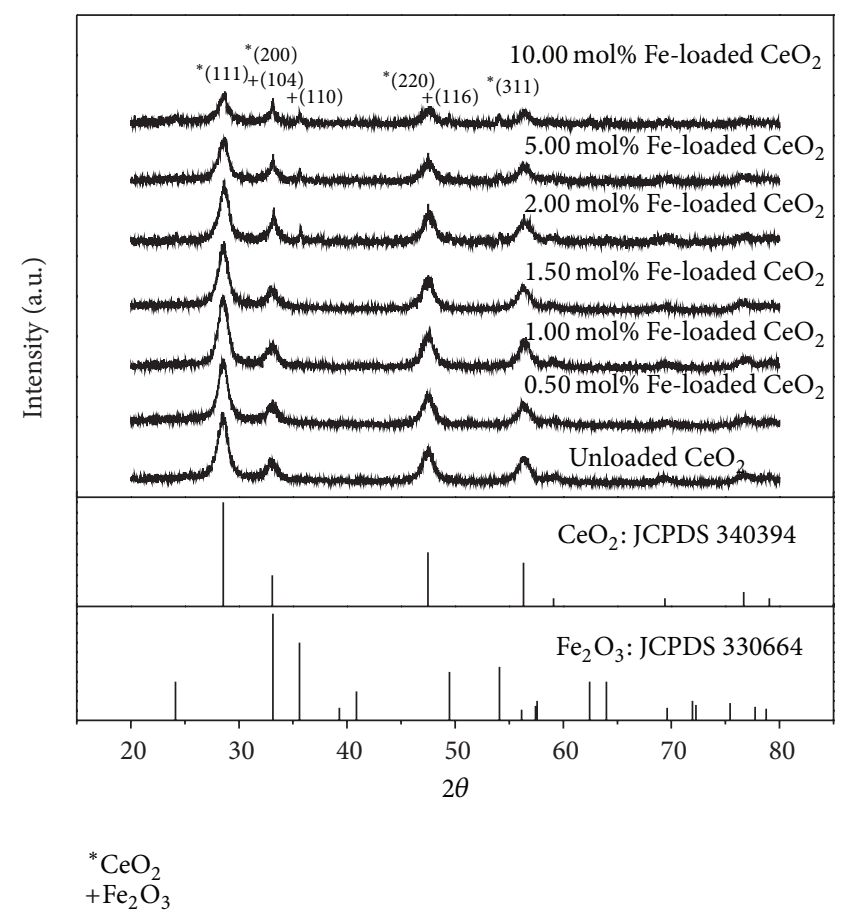

FIGURE 1: X-ray diffraction patterns of $\mathrm{CeO}_{2}$ with different iron content.

and Teller (BET) nitrogen adsorption method (QuantachromeAutosorp $1 \mathrm{MP}$ ). The reflectance spectra of the nanoparticle powders were obtained by using UV-visible diffuse reflectance spectrophotometry (UV-vis DRS) equipped with integrating sphere detector (Shimadzu, UV-3101PC).

2.3. Photocatalytic Activity. $1.00 \mathrm{~g} / \mathrm{L}$ of photocatalyst suspensions was prepared in deionized water and circulated in closed system spiral photoreactor. In a typical run, carbon burn-off step was firstly carried out by illuminating the photocatalyst suspension with a UV-A lamp (Sylvania Blacklight Blue, $18 \mathrm{~W}$ ) in order to remove any organic impurities from the photocatalyst. The photocatalytic activities were evaluated through formic acid (Sigma-Aldrich, $98 \mathrm{wt} \%$ ) and oxalic acid (Sigma-Aldrich, 99.99 wt\%) degradations under the visible irradiation for $120 \mathrm{~min}$. Finally, the generated carbon dioxide $\left(\mathrm{CO}_{2}\right)$ was measured using the conductivity meter (Eutech Instruments Cyberscan PC5500, $\mu \mathrm{S} / \mathrm{cm}^{2}$ precision). At the end of each photocatalytic experiment, the recorded data presented the increase in conductivity value. In order to calculate amounts of generated $\mathrm{CO}_{2}$, the values were converted from conductivity at that time to the amount of carbon by the interpolated from calibration curve.

\section{Results and Discussion}

3.1. X-Ray Powder Diffraction (XRD). In Figure 1, the X-ray diffraction pattern has been used in order to study the structure and phase composition of the prepared samples. It can be seen that all samples had similar diffraction patterns of cubic fluorite structure of ceria (JCPDS 340394) [39]. However, 
TABLE 1: The calculated $d$-spacing, lattice parameters, unit cell volume, and crystalline size.

\begin{tabular}{lccccc}
\hline $\begin{array}{l}\text { Iron loading } \\
\text { concentration (mol\%) }\end{array}$ & $2 \theta$ (degree) & $d$-spacing $(\mathrm{nm})$ & Lattice parameter $(\mathrm{nm})$ & Unit cell volume $\left(\mathrm{nm}^{3}\right)$ & Crystalline size $(\mathrm{nm})$ \\
\hline 0.00 & 28.4601 & 0.3132 & 0.5426 & 0.1597 & 8.3586 \\
0.50 & 28.5479 & 0.3123 & 0.5409 & 0.1583 & 7.8555 \\
1.00 & 28.5699 & 0.3121 & 0.5405 & 0.1579 & 7.4111 \\
1.50 & 28.5772 & 0.3120 & 0.5404 & 0.1578 & 7.4081 \\
2.00 & 28.6284 & 0.3114 & 0.5394 & 0.1570 & 6.9682 \\
5.00 & 28.6490 & 0.3112 & 0.5390 & 0.1566 & 6.2226 \\
10.00 & 28.7098 & 0.3106 & 0.5380 & 0.1557 & 5.7476 \\
\hline
\end{tabular}

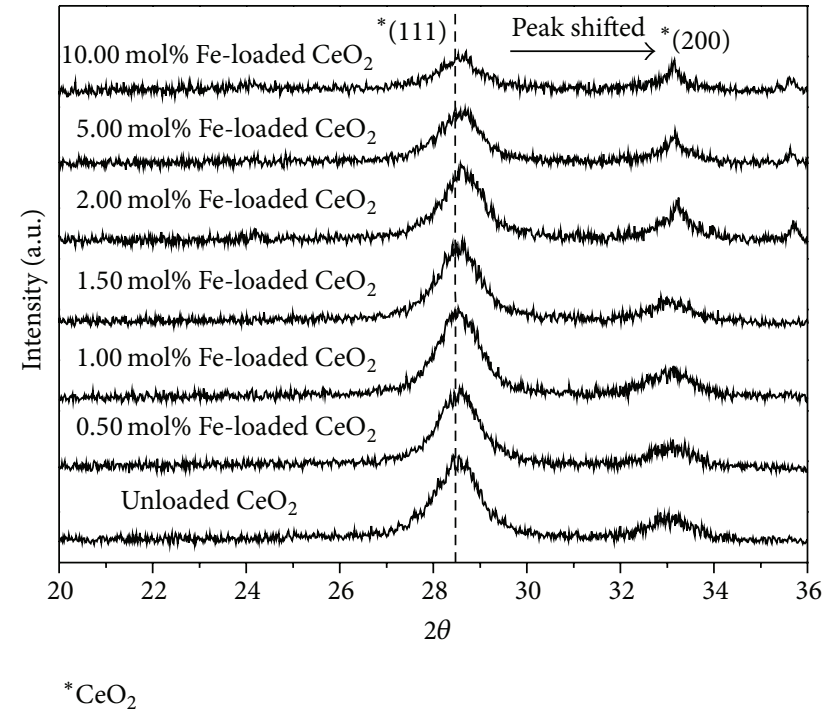

FIgURE 2: The shift of $2 \theta$ of samples.

the sample with high amount of iron loading $(2.00,5.00$, and $10.00 \mathrm{~mol} \%)$ exhibited the mixed phase of $\mathrm{CeO}_{2}$ and $\mathrm{Fe}_{2} \mathrm{O}_{3}$ (JCPDS 330664) [40]. The XRD peaks of all samples were magnified as shown in Figure 2. It was found that $\mathrm{CeO}_{2}$ peaks shifted towards higher $2 \theta$ upon increasing iron content. The calculated $d$-spacing, lattice parameter, unit cell volume, and average crystallite size were also decreased as shown in Table 1. These observations could be ascribed to partial substitution of $\mathrm{Ce}^{4+}$ ions $(0.101 \mathrm{~nm})$ by $\mathrm{Fe}^{3+}$ ions $(0.064 \mathrm{~nm})$ [41]. A decrease of unit cell parameters due to the substitution of larger ion by the smaller one was also found in previous reports $[42,43]$.

\subsection{High-Resolution Transmission Electron Microscopy} (HRTEM). As seen from Figure 3(a), the unloaded $\mathrm{CeO}_{2}$ clearly showed the cubic morphology of cubic fluorite $\mathrm{CeO}_{2}$ structure. In Figure 3(b), the particles became more spherical upon loading $\mathrm{CeO}_{2}$ with iron. This change in $\mathrm{CeO}_{2}$ morphology might be due to the incorporation of iron ions in $\mathrm{CeO}_{2}$ lattice, thus affecting the particle growth and causing lattice deformation [44]. This assumption was supported by the shift of XRD peak and the changes of lattice
TABLE 2: Summary of analytical data.

\begin{tabular}{lccc}
\hline $\begin{array}{l}\text { Iron loading } \\
\text { concentration } \\
(\mathrm{mol} \%)\end{array}$ & SSA $\left(\mathrm{m}^{2} / \mathrm{g}\right)$ & $E_{g}(\mathrm{eV})$ & $\begin{array}{c}\text { BET diameter } \\
(\mathrm{nm})\end{array}$ \\
\hline 0 & 130.00 & 3.21 & 6.39 \\
0.50 & 134.00 & 2.95 & 6.20 \\
1.00 & 137.97 & 2.70 & 6.02 \\
1.50 & 137.99 & 2.65 & 6.02 \\
2.00 & 139.00 & 2.55 & 5.98 \\
5.00 & 140.82 & 2.45 & 5.57 \\
10.00 & 148.76 & 2.35 & 5.27 \\
\hline
\end{tabular}

parameters as reported in Table 1 . The average particle sizes as seen from HRTEM image were about $6-8 \mathrm{~nm}$. This was in good agreement with the calculated sizes obtained by using the Scherrer equation. Figure 3(c) shows the lattice fringes of $2.00 \mathrm{~mol} \% \mathrm{Fe}-$ loaded $\mathrm{CeO}_{2}$. The lattice planes with $d$-spacing of 0.16 and $0.20 \mathrm{~nm}$ were attributed to the (311) and (220) planes of cubic fluorite $\mathrm{CeO}_{2}$, respectively, whereas the plane with $d$-spacing of 0.24 was assigned to the (110) plane of $\mathrm{Fe}_{2} \mathrm{O}_{3}$. These results confirmed the presence of mixed phase between $\mathrm{CeO}_{2}$ and $\mathrm{Fe}_{2} \mathrm{O}_{3}$ in the nominal $2.00 \mathrm{~mol} \%$ Fe-loaded $\mathrm{CeO}_{2}$ as found previously in the XRD patterns (Figure 1).

3.3. Nitrogen Adsorption-Desorption Isotherms. The specific surface areas (SSA) of different samples were analyzed by Brunauer-Emmett-Teller (BET) method based on the nitrogen adsorption/desorption isotherm. The mean BET diameter $(D)$ was also calculated by using the following equation [45]:

$$
D=\frac{6000}{\left(S_{\mathrm{BET}} \times \rho\right)},
$$

where $S_{\mathrm{BET}}$ is the BET-specific surface area and $\rho$ is the density of the $\mathrm{CeO}_{2}(7.32 \mathrm{~g} / \mathrm{mL})$. As shown in Table 2 , an increase of surface area accompanied with a decrease of BET diameter was clearly observed upon increasing iron content. This increased surface area would be beneficial to the efficient photocatalytic performance due to high surface adsorption of organic pollutants. The calculated BET diameter was in 


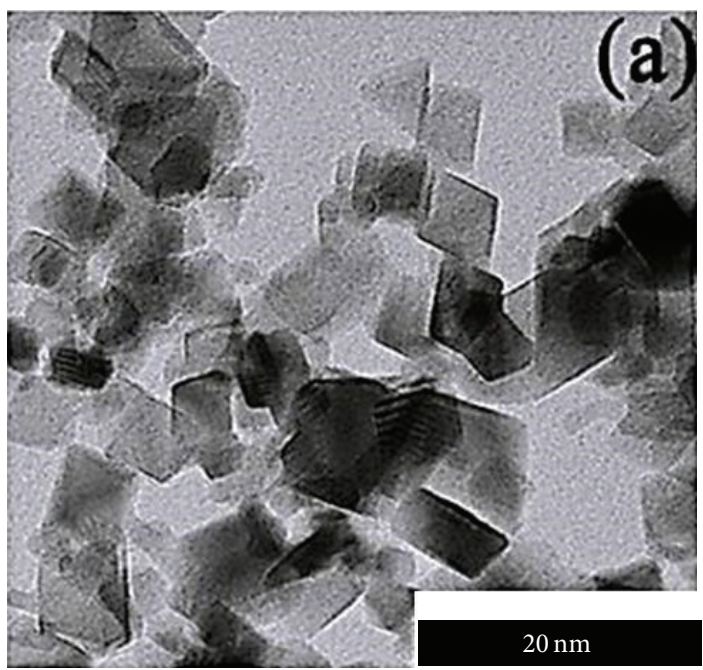

(a)

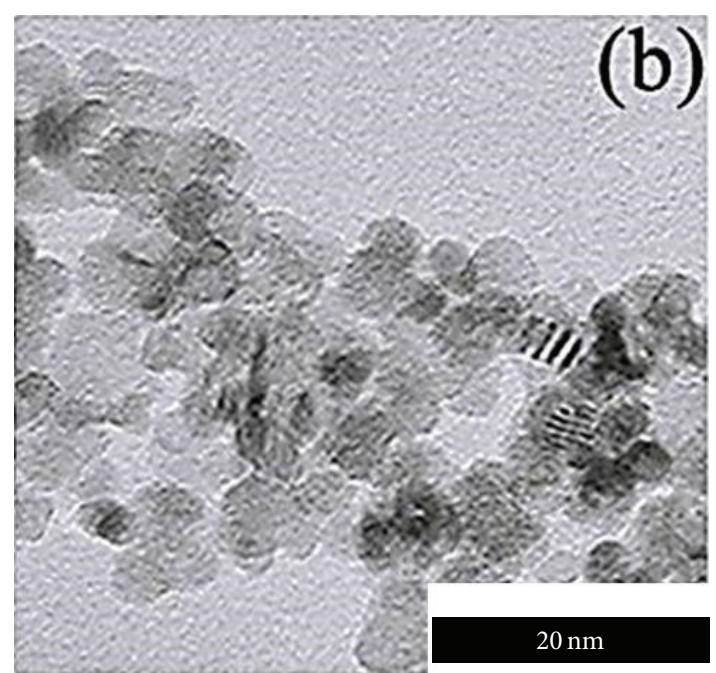

(b)

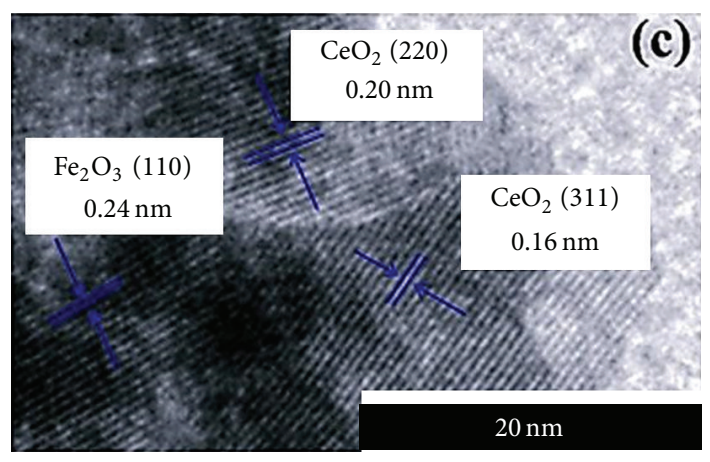

(c)

Figure 3: HRTEM images of (a) unloaded $\mathrm{CeO}_{2}$, (b) 2.00 mol\% Fe-loaded $\mathrm{CeO}_{2}$, and (c) lattice fringe of $2.00 \mathrm{~mol} \% \mathrm{Fe}-\mathrm{loaded} \mathrm{CeO}$.

the range of 5-7 nm which was very well in agreement with those obtained by using the Scherrer equation (Table 1).

3.4. UV-Visible Spectroscopy. UV-vis reflectance analysis was performed by converting the obtained reflectance spectra (Figure 4(a)) to the Kubelka-Munk absorbance spectra using the Kubelka-Munk equation as follows [46]:

$$
F\left(R_{\infty}\right)=\frac{\left(1-R_{\infty}\right)^{2}}{2 R_{\infty}}
$$

where $F\left(R_{\infty}\right)$ and $R_{\infty}$ are the Schuster-Kubelka-Munk absorbance and the absolute reflectance of the sample, respectively. The plot of absorbance against wavelength for the $\mathrm{CeO}_{2}$ nanoparticle powders is shown in Figure 4(b).

The spectra showed that the absorption edge shifted to longer wavelength upon increasing the iron loading concentration. Band gap energies of the obtained samples can then be determined by using the intercept of the tangent to the graph plotting between the Kubelka-Munk absorption function and photon energy $(h \nu)$ as shown in Figure 4(c) $[47,48]$. The obtained band gap energies $\left(E_{g}\right)$ as reported in Table 2 decreased with increasing iron loading concentration.
3.5. Photocatalytic Activity. The photocatalytic activity of unloaded and Fe-loaded $\mathrm{CeO}_{2}$ was evaluated by degradation of formic and oxalic acids. The effects of different iron loading concentrations on the photocatalytic efficiency of $\mathrm{CeO}_{2}$ nanoparticles were evaluated under visible-light irradiation for $120 \mathrm{~min}$, and the results are presented in Figure 5. According to the results, the photocatalytic activities of Fe-loaded $\mathrm{CeO}_{2}$ nanoparticles were significantly higher than those of unloaded $\mathrm{CeO}_{2}$ nanoparticles. This improved photoactivity could be partially ascribed to the enhanced light absorption in visible-light region as observed from the UV-vis study in Figure 4. However, the activity was clearly dependent on the amount of iron loading. The results demonstrated that the nominal $2.00 \mathrm{~mol} \%$ was an optimal iron concentration for photocatalytic activity of $\mathrm{CeO}_{2}$ nanoparticles in this research. On the other hand, $5.00 \%$ and $10.00 \mathrm{~mol} \%$ iron concentrations showed poor photocatalytic activity, probably because high iron concentration tended to cover $\mathrm{CeO}_{2}$ surface, thus preventing light from contacting the $\mathrm{CeO}_{2}$ surface [49].

Another possible reason was that too high iron loading can act as the electron-hole recombination centers instead of the trapping level, resulting in a decreased photocatalytic activity $[47,50]$. The kinetic data for formic and oxalic acids degradations under visible-light illumination were found to 


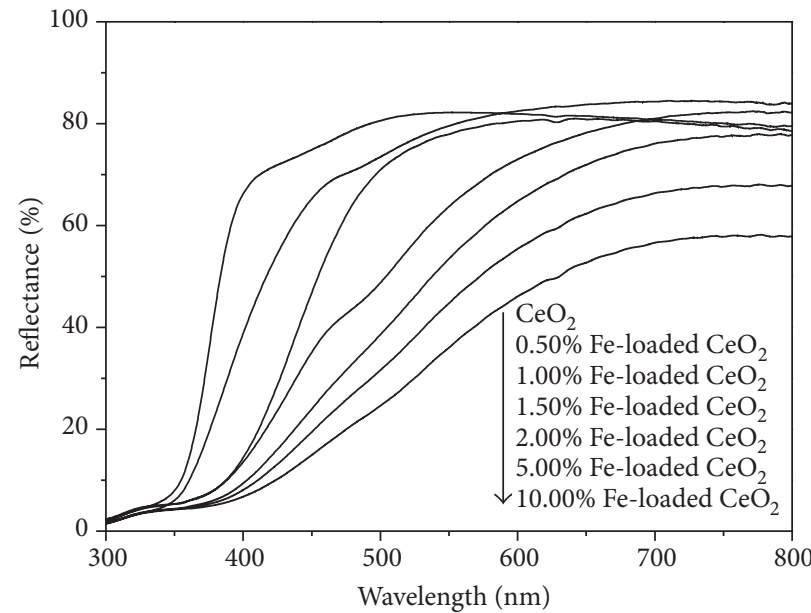

(a)

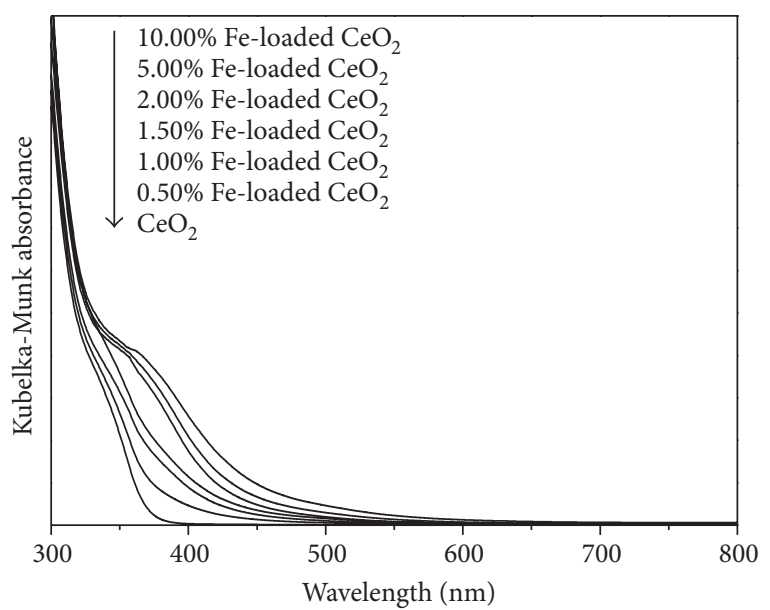

(b)

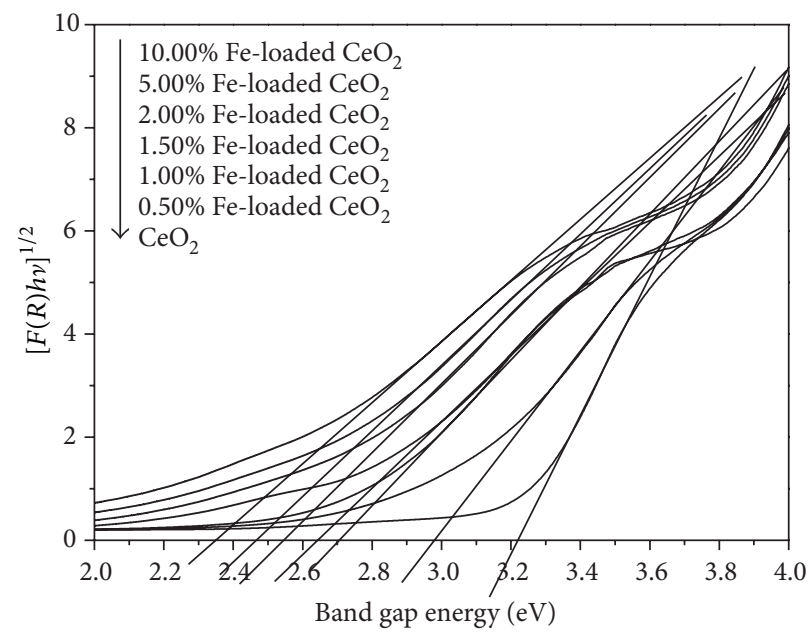

(c)

Figure 4: UV-vis (a) reflection spectra, (b) Kubelka-Munk absorbance, and (c) relation between band gap energy and $[F(R) h \nu]^{1 / 2}$ of $\mathrm{CeO}_{2}$ with different iron content.

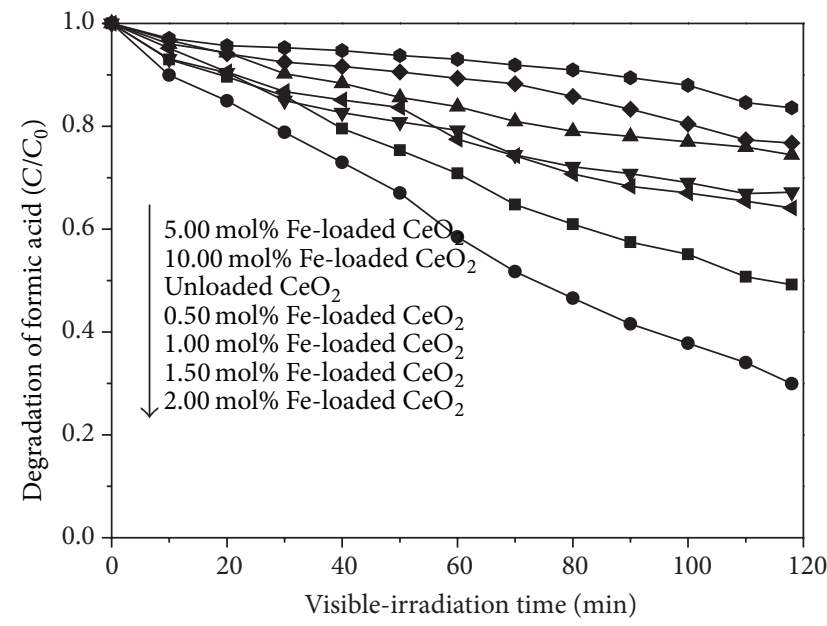

(a)

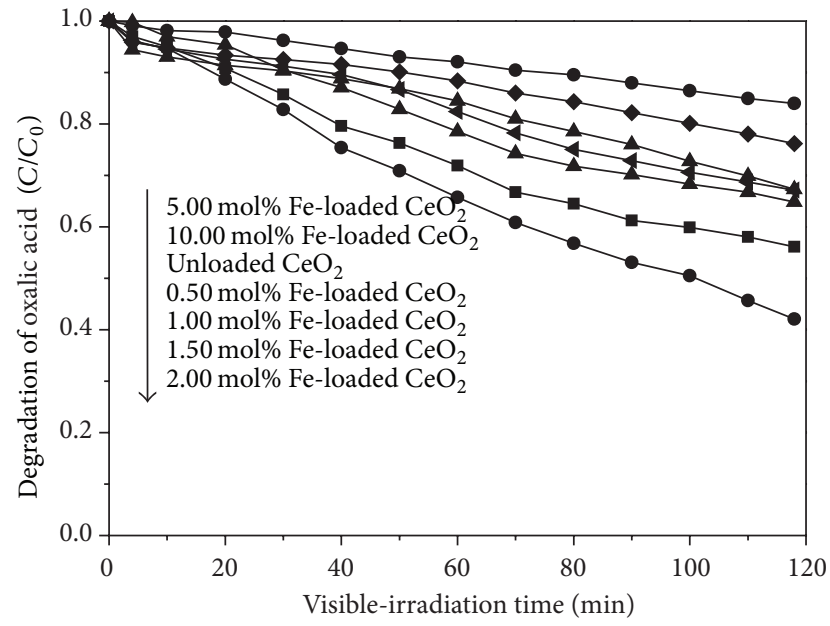

(b)

Figure 5: Photocatalytic degradation of (a) formic acid and (b) oxalic acid by $\mathrm{CeO}_{2}$ with different iron content as a function of visible-light irradiation time. 


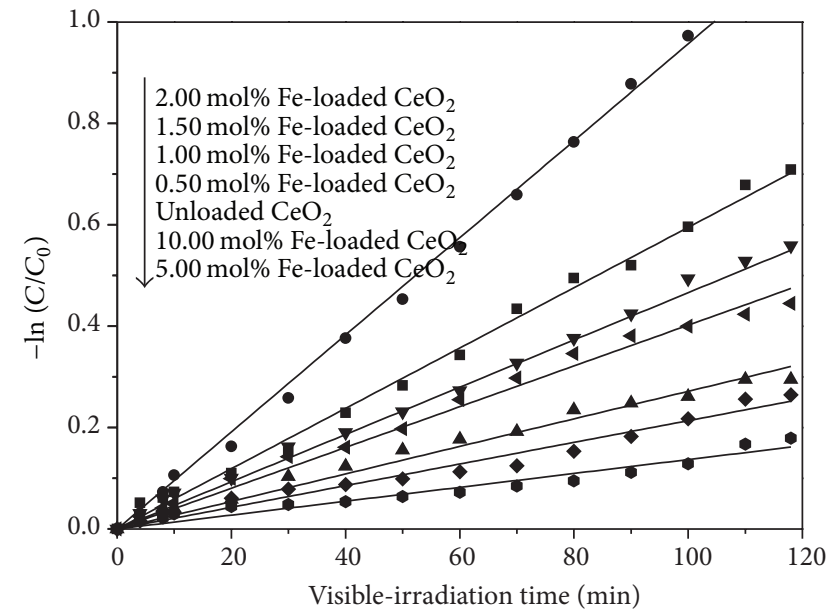

(a)

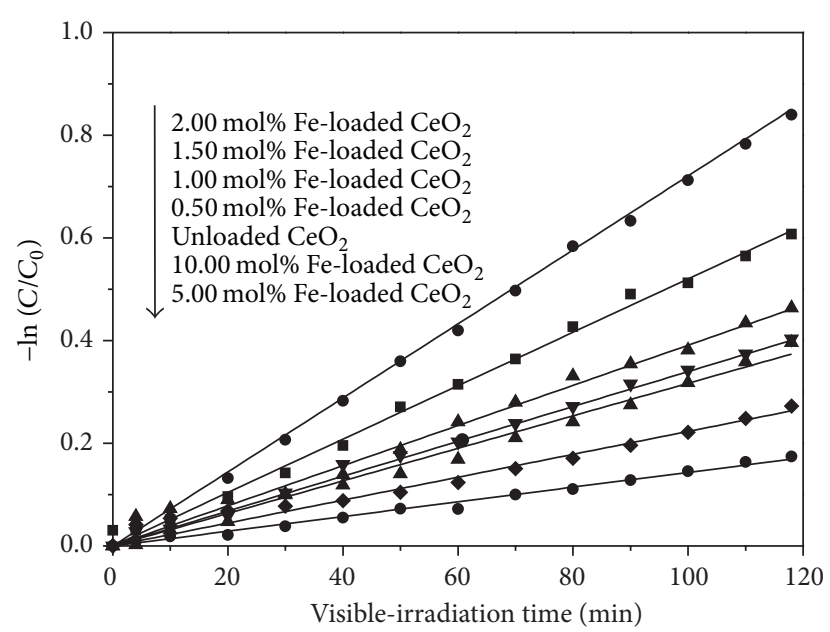

(b)

FIGURE 6: Kinetics plots for linear fitting of data obtained from pseudo first-order reaction for (a) formic acid and (b) oxalic acid degradation under visible-light irradiation.

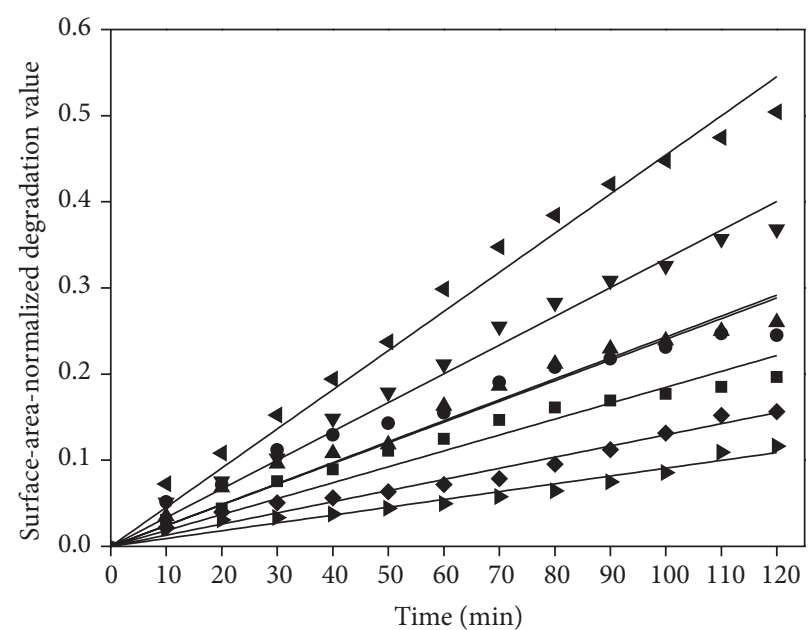

- Bare $\mathrm{CeO}_{2}$

- $0.50 \%$ Fe-loaded $\mathrm{CeO}_{2}$

- $1.00 \%$ Fe-loaded $\mathrm{CeO}_{2}$

$\nabla 1.50 \%$ Fe-loaded $\mathrm{CeO}_{2}$

(a)

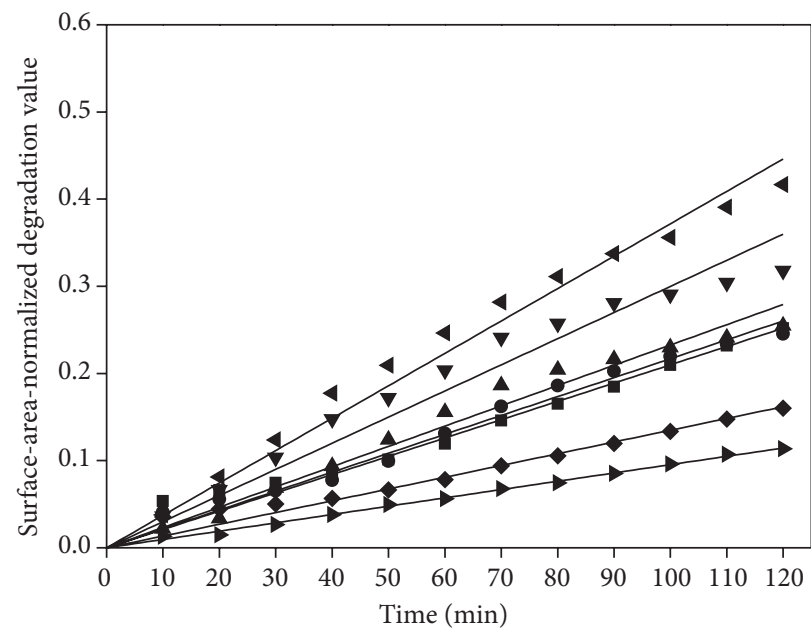

- Bare $\mathrm{CeO}_{2}$

- $0.50 \% \mathrm{Fe}$-loaded $\mathrm{CeO}_{2}$

- $1.00 \%$ Fe-loaded $\mathrm{CeO}_{2}$

v $1.50 \% \mathrm{Fe}$-loaded $\mathrm{CeO}_{2}$

\2.00\% Fe-loaded $\mathrm{CeO}_{2}$

- $5.00 \%$ Fe-loaded $\mathrm{CeO}_{2}$

- $10.00 \%$ Fe-loaded $\mathrm{CeO}_{2}$

(b)

FIGURE 7: Kinetics plots of the surface-area-normalized degradation values against visible-light irradiation time for (a) formic acid and (b) oxalic acid.

follow pseudo first-order reaction [51] as shown in Figure 6. The pseudo first-order model is explained by

$$
-\ln \left(\frac{C}{C_{0}}\right)=k t,
$$

where $k$ is the apparent rate constant $\left(\mathrm{min}^{-1}\right), C_{0}$ means the initial concentration of acid, and $C$ refers to the concentration of acid at various reaction times $(t)$. The determined pseudo first-order rate constants $\left(k, \min ^{-1}\right)$ are presented in Table 3 . It can be seen that the loading of $2.00 \mathrm{~mol} \%$ iron in $\mathrm{CeO}_{2}$ nanoparticles could remarkably improve the apparent rate constant up to 5 times for formic acid and 3 times for oxalic acid compared with the unloaded one.

In order to investigate the effect of surface area on the degradation activity, the surface-area-normalized degradation values against visible-light irradiation time were plotted as shown in Figure 7, and the calculated surface-area-normalized rate constants are presented in Table 3 . The results clearly suggested that surface-area of the catalyst has a crucial impact on the activity of acid degradation in this study because the surface area-normalized rate constants are significantly decreased from the original values. However, other factors such as band gap energy, amount of Fe loading, 
TABLE 3: Apparent rate constants and surface-area-normalized rate constants.

\begin{tabular}{lcccc}
\hline \multirow{2}{*}{ Samples } & \multicolumn{2}{c}{ Rate constant $\left(k, \mathrm{~min}^{-1}\right)$} & Surface-area-normalized rate constants $\left(\mathrm{min}^{-1} \mathrm{~m}^{-2} \mathrm{~g}\right)$ \\
Formic acid & Oxalic acid & Formic acid & 0.0010 \\
\hline 5.00 mol\% Fe-loaded $\mathrm{CeO}_{2}$ & 0.0014 & 0.0014 & 0.0009 & 0.0014 \\
10.00 mol\% Fe-loaded $\mathrm{CeO}_{2}$ & 0.0017 & 0.0020 & 0.0013 & 0.0021 \\
Unloaded $\mathrm{CeO}_{2}$ & 0.0021 & 0.0022 & 0.0019 & 0.0022 \\
$0.50 \mathrm{~mol} \% \mathrm{Fe}-$ loaded $\mathrm{CeO}_{2}$ & 0.0040 & 0.0034 & 0.0024 & 0.0023 \\
$1.00 \mathrm{~mol} \% \mathrm{Fe}-$ loaded $\mathrm{CeO}_{2}$ & 0.0054 & 0.0039 & 0.0024 & 0.0030 \\
$1.50 \mathrm{~mol} \% \mathrm{Fe}-$ loaded $\mathrm{CeO}_{2}$ & 0.0060 & 0.0052 & 0.0033 & 0.0037 \\
$2.00 \mathrm{~mol} \% \mathrm{Fe}-$ loaded $\mathrm{CeO}_{2}$ & 0.0096 & 0.0072 & 0.0045 & \\
\hline
\end{tabular}

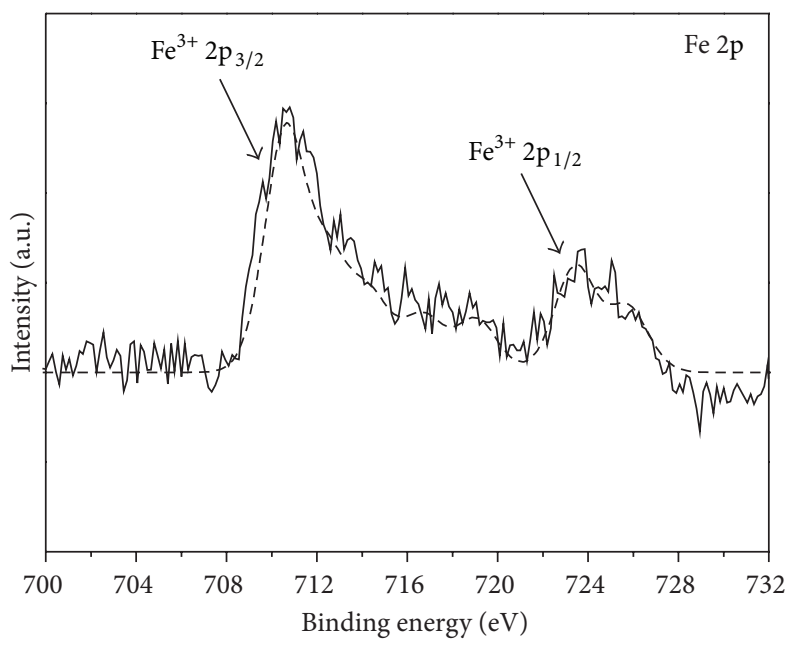

(a)

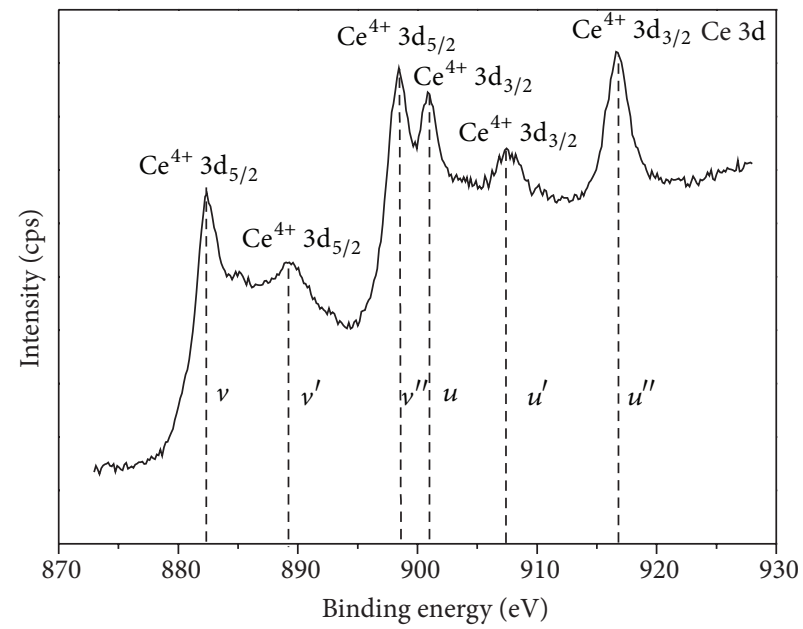

(b)

FIgure 8: The XPS spectra of Fe-loaded $\mathrm{CeO}_{2}$ nanoparticles: (a) Fe 2p and (b) Ce 3d.

sample crystallinity, and phase composition [52] could not be neglected as these could also contribute to the difference in photocatalytic activity of the catalysts being studied.

3.6. X-Ray Photoelectron Spectroscopy (XPS). In order to characterize the valence state of cerium and iron in $2.00 \mathrm{~mol} \%$ Fe-loaded $\mathrm{CeO}_{2}$, X-ray photoelectron spectroscopy (XPS) was carried out as shown in Figure 8.

According to Figure 8(a), the peaks at 710.6 and $723.4 \mathrm{eV}$ assignable to the core level of $2 \mathrm{p}_{3 / 2}$ and $2 \mathrm{p}_{1 / 2}$, respectively, corresponded to $\mathrm{Fe}^{3+}$ species in $\mathrm{Fe}_{2} \mathrm{O}_{3}[53,54]$. No other peaks due to $\mathrm{Fe}^{0}$ and $\mathrm{Fe}^{2+}$ were found in the XPS results. From the Ce $3 d$ XPS spectrum, the binding energies of all peaks are shown in Figure 8(b). These peaks corresponded to the three pairs of spin-orbit doublets assignable to $\mathrm{Ce}^{4+}$ valence state which were very well in agreement with the previous reports $[55,56]$.

\section{Conclusions}

Fe-loaded $\mathrm{CeO}_{2}$ nanoparticles with different iron loading concentrations have successfully been synthesized by flame spray pyrolysis (FSP). Loading $\mathrm{CeO}_{2}$ with $\mathrm{Fe}^{3+}$ resulted in a decrease of $d$-spacing, lattice parameter, unit cell volume, and crystallite size but an increase of BET surface area. The UVvis absorption spectra displayed a red shift in the band edge transition upon increasing of iron loading concentration. XPS analysis showed the presence of $\mathrm{Fe}^{3+}$ species on the surface of $\mathrm{CeO}_{2}$. This could be attributed to the presence of $\mathrm{Fe}_{2} \mathrm{O}_{3}$ as observed from the XRD and HRTEM analyses. Increased photocatalytic activity compared with unloaded $\mathrm{CeO}_{2}$ was clearly obtained from the Fe-loading sample. It was found from this study that the nominal $2.00 \mathrm{~mol} \%$ was an optimum iron loading concentration, giving the highest photocatalytic activity. Band gap energy and surface of the catalyst were found to be important factors affecting the photocatalytic activity observed in this study. However, other factors such as amount of Fe loading, sample crystallinity, and phase composition could not be neglected.

\section{Acknowledgments}

This work has been supported by Thailand Research Fund (TRF) through the Royal Golden Jubilee (RGJ) Ph.D. Program. The National Research University Project under Thailand's Office of Higher Education Commission; the Materials Science Research Center, Department of Chemistry, Faculty of Science; and the Graduate School, Chiang Mai University, are greatly acknowledged. 


\section{References}

[1] J. Nowotny, C. C. Sorrell, L. R. Sheppard, and T. Bak, "Solarhydrogen: environmentally safe fuel for the future," International Journal of Hydrogen Energy, vol. 30, no. 5, pp. 521-544, 2005.

[2] T. L. Thompson and J. T. Yates Jr., "Surface science studies of the photoactivation of $\mathrm{TiO}_{2}$-new photochemical processes," Chemical Reviews, vol. 106, no. 10, pp. 4428-4453, 2006.

[3] J. Zhao, C. Chen, and W. Ma, "Photocatalytic degradation of organic pollutants under visible light irradiation," Topics in Catalysis, vol. 35, no. 3-4, pp. 269-278, 2005.

[4] I. N. Martyanov, S. Uma, S. Rodrigues, and K. J. Klabunde, "Structural defects cause $\mathrm{TiO}_{2}$-based photocatalysts to be active in visible light," Chemical Communications, vol. 10, no. 21, pp. 2476-2477, 2004.

[5] I. N. Martyanov, T. Berger, O. Diwald, S. Rodrigues, and K. J. Klabunde, "Enhancement of $\mathrm{TiO}_{2}$ visible light photoactivity through accumulation of defects during reduction-oxidation treatment," Journal of Photochemistry and Photobiology A, vol. 212, no. 2-3, pp. 135-141, 2010.

[6] W. Liu and M. Flytzani-Stephanopoulos, "Transition metalpromoted oxidation catalysis by fluorite oxides: a study of $\mathrm{CO}$ oxidation over $\mathrm{Cu}-\mathrm{CeO}_{2}$," Chemical Engineering Journal and the Biochemical Engineering Journal, vol. 64, no. 2, pp. 283-294, 1996.

[7] G. R. Rao, J. Kašpar, S. Meriani, R. di Monte, and M. Graziani, "NO decomposition over partially reduced metallized $\mathrm{CeO}_{2}-$ $\mathrm{ZrO}_{2}$ solid solutions," Catalysis Letters, vol. 24, no. 1-2, pp. 107112, 1994.

[8] J. Kašpar, P. Fornasiero, and N. Hickey, "Automotive catalytic converters: current status and some perspectives," Catalysis Today, vol. 77, no. 4, pp. 419-449, 2003.

[9] Y. Li, Q. Fu, and M. Flytzani-Stephanopoulos, "Low-temperature water-gas shift reaction over $\mathrm{Cu}$ - and Ni-loaded cerium oxide catalysts," Applied Catalysis B, vol. 27, no. 3, pp. 179-191, 2000.

[10] G. Neri, A. Pistone, C. Milone, and S. Galvagno, "Wet air oxidation of p-coumaric acid over promoted ceria catalysts," Applied Catalysis B, vol. 38, no. 4, pp. 321-329, 2002.

[11] C. Ho, J. C. Yu, T. Kwong, A. C. Mak, and S. Lai, "Morphologycontrollable synthesis of mesoporous $\mathrm{CeO}_{2}$ nano- and microstructures," Chemistry of Materials, vol. 17, no. 17, pp. 4514-4522, 2005.

[12] M. I. Litter, "Heterogeneous photocatalysis: transition metal ions in photocatalytic systems," Applied Catalysis B, vol. 23, no. 2-3, pp. 89-114, 1999.

[13] S. Tuprakay and W. Liengcharernsit, "Lifetime and regeneration of immobilized titania for photocatalytic removal of aqueous hexavalent chromium," Journal of Hazardous Materials, vol. 124, no. 1-3, pp. 53-58, 2005.

[14] W. Choi, A. Termin, and M. R. Hoffmann, "The role of metal ion dopants in quantum-sized $\mathrm{TiO}_{2}$ : correlation between photoreactivity and charge carrier recombination dynamics," Journal of Physical Chemistry, vol. 98, no. 51, pp. 13669-13679, 1994.

[15] S. Kaur and V. Singh, "Visible light induced sonophotocatalytic degradation of reactive red dye 198 using dye sensitized $\mathrm{TiO}_{2}$," Ultrasonics Sonochemistry, vol. 14, no. 5, pp. 531-537, 2007.

[16] M. Grätzel, "Photoelectrochemical cells," Nature, vol. 414, no. 6861, pp. 338-344, 2001.

[17] H. J. Avila-Paredes, P. Jain, S. Sen, and S. Kim, "Oxygen transport in Sc-doped $\mathrm{CeO}_{2}$ : cation $(45 \mathrm{Sc}) \mathrm{NMR}$ as a probe of anionic conductivity," Chemistry of Materials, vol. 22, no. 3, pp. 893-897, 2010

[18] Z. Hong, H. Yoshida, and T. Sakuma, "High temperature creep strength of $\mathrm{Si}_{3} \mathrm{~N}_{4}-\mathrm{Y}_{2} \mathrm{Si}_{2} \mathrm{O}_{7}$ ceramics by stress relaxation based on a new interpretation model," Key Engineering Materials, vol. 336-338, pp. 1420-1423, 2007.

[19] P. Panagiotopoulou, J. Papavasiliou, G. Avgouropoulos, T. Ioannides, and D. I. Kondarides, "Water-gas shift activity of doped $\mathrm{Pt} / \mathrm{CeO}_{2}$ catalysts," Chemical Engineering Journal, vol. 134, no. 1-3, pp. 16-22, 2007.

[20] C. Kitiwiang and S. Phanichphant, "Synthesis of silver-doped cerium dioxide nanoparticles by the homogeneous precipitation," Journal of Microscopy Society of Thailand, vol. 23, no. 1, pp. 83-86, 2009.

[21] S. Maensiri, S. Phokha, P. Laokul, and S. Seraphin, "Room temperature ferromagnetism in $\mathrm{Fe}$-doped $\mathrm{CeO}_{2}$ nanoparticles," Journal of Nanoscience and Nanotechnology, vol. 9, no. 11, pp. 6415-6420, 2009.

[22] C. Xia, C. Hu, P. Chen, B. Wan, X. He, and Y. Tian, "Magnetic properties and photoabsorption of the $\mathrm{Mn}$-doped $\mathrm{CeO}_{2}$ nanorods," Materials Research Bulletin, vol. 45, no. 7, pp. 794798, 2010.

[23] J. Sacanell, M. A. Paulin, V. Ferrari, G. Garbarino, and A. G. Leyva, "Surface photoluminescence and magnetism in hydrothermally grown undoped $\mathrm{ZnO}$ nanorod arrays," Applied Physics Letters, vol. 100, no. 11, pp. 172401-172405, 2012.

[24] S. Kumar, Y. J. Kim, B. H. Koo, and C. G. Lee, "Structural and magnetic properties of $\mathrm{Ni}$ doped $\mathrm{CeO}_{2}$ nanoparticles," Journal of Nanoscience and Nanotechnology, vol. 10, no. 11, pp. 72047207, 2010.

[25] T. S. Santos, W. S. D. Folly, and M. A. Macêdo, "Ferromagnetism in diluted magnetic $\mathrm{Zn}$-Co-doped $\mathrm{CeO}_{2-\delta}$," Physica B: Condensed Matter, vol. 407, no. 16, pp. 3233-3235, 2012.

[26] J. Araña, O. González Díaz, M. Miranda Saracho, J. M. Doa Rodríguez, J. A. Herrera Melián, and J. Pérez Pea, "Photocatalytic degradation of formic acid using $\mathrm{Fe} / \mathrm{TiO}_{2}$ catalysts: the role of $\mathrm{Fe}^{3+} / \mathrm{Fe}^{2+}$ ions in the degradation mechanism," Applied Catalysis B, vol. 32, no. 1-2, pp. 49-61, 2001.

[27] Q.-Z. Yan, X.-T. Su, Z.-Y. Huang, and C.-C. Ge, "Sol-gel autoigniting synthesis and structural property of cerium-doped titanium dioxide nanosized powders," Journal of the European Ceramic Society, vol. 26, no. 6, pp. 915-921, 2006.

[28] L. Yin, Y. Wang, G. Pang, Y. Koltypin, and A. Gedanken, "Sonochemical synthesis of cerium oxide nanoparticles-effect of additives and quantum size effect," Journal of Colloid and Interface Science, vol. 246, no. 1, pp. 78-84, 2002.

[29] L. Truffault, Q. W. Yao, D. Wexler et al., "Synthesis and characterization of $\mathrm{Fe}$ doped $\mathrm{CeO}_{2}$ nanoparticles for pigmented ultraviolet filter applications," Journal of Nanoscience and Nanotechnology, vol. 11, no. 5, pp. 4019-4028, 2011.

[30] M. Hirano and M. Inagaki, "Preparation of monodispersed cerium(IV) oxide particles by thermal hydrolysis: influence of the presence of urea and Gd doping on their morphology and growth," Journal of Materials Chemistry, vol. 10, no. 2, pp. 473477, 2000.

[31] A. Bumajdad, M. I. Zaki, J. Eastoe, and L. Pasupulety, "Microemulsion-based synthesis of $\mathrm{CeO}_{2}$ powders with high surface area and high-temperature stabilities," Langmuir, vol. 20, no. 25, pp. 11223-11233, 2004.

[32] D. Terribile, A. Trovarelli, J. Llorca, C. De Leitenburg, and G. Dolcetti, "The synthesis and characterization of mesoporous 
high-surface area ceria prepared using a hybrid organic/inorganic route," Journal of Catalysis, vol. 178, no. 1, pp. 299-308, 1998.

[33] L. Mädler, W. J. Stark, and S. E. Pratsinis, "Flame-made ceria nanoparticles," Journal of Materials Research, vol. 17, no. 6, pp. 1356-1362, 2002.

[34] R. Mueller, L. Mädler, and S. E. Pratsinis, "Nanoparticle synthesis at high production rates by flame spray pyrolysis," Chemical Engineering Science, vol. 58, no. 10, pp. 1969-1976, 2003.

[35] L. Mädler, T. Sahm, A. Gurlo et al., "Sensing low concentrations of $\mathrm{CO}$ using flame-spray-made $\mathrm{Pt} / \mathrm{SnO}_{2}$ nanoparticles," Journal of Nanoparticle Research, vol. 8, no. 6, pp. 783-796, 2006.

[36] T. Samerjai, N. Tamaekonga, K. Wetchakun et al., "Flame-spraymade metal-loaded semiconducting metal oxides thick films for flammable gas sensing," Sensors and Actuators B, vol. 171-172, pp. 43-61, 2012.

[37] C. Liewhiran and S. Phanichphant, "Effects of palladium loading on the response of a thick film flame-made $\mathrm{ZnO}$ gas sensor for detection of ethanol vapor," Sensors, vol. 7, no. 7, pp. 11591184, 2007.

[38] B. Li, X. Wang, M. Yan, and L. Li, "Preparation and characterization of nano- $\mathrm{TiO}_{2}$ powder," Materials Chemistry and Physics, vol. 78, no. 1, pp. 184-188, 2003.

[39] A. Gupta, M. S. Hegde, K. R. Priolkar, U. V. Waghmare, P. R. Sarode, and S. Emura, "Structural investigation of activated lattice oxygen in $\mathrm{Ce}_{1-x} \mathrm{Sn}_{x} \mathrm{O}_{2}$ and $\mathrm{Ce}_{1-x-y} \mathrm{Sn}_{x} \mathrm{PdyO}_{2-\delta}$ by EXAFS and DFT calculation," Chemistry of Materials, vol. 21, no. 24, pp. 5836-5847, 2009.

[40] T. Nishimura, H. Katayama, K. Noda, and T. Kodama, "Electrochemical behavior of rust formed on carbon steel in a wet/dry environment containing chloride ions," Corrosion, vol. 56, no. 9, pp. 935-941, 2000.

[41] R. D. Shannon, "Revised effective ionic radii and systematic studies of interatomie distances in halides and chaleogenides," Acta Crystallographica Section A, vol. 32, no. 5, pp. 751-767, 1976.

[42] G. L. Beausoleil, A. Thurber, S. S. Rao, G. Alanko, C. B. Hanna, and A. Punnoose, "Concentration dependence of magnetic moment in $\mathrm{Ce}_{1-x} \mathrm{Fe}_{x} \mathrm{O}_{2}$," Journal of Applied Physics, vol. 111, no. 7, pp. 1-9, 2012.

[43] N. Wu, L. Chen, Y. Jiao, G. Chen, and J. Li, "Preparation and characterization of $\mathrm{Fe}^{3+}, \mathrm{La}^{3+} \mathrm{Co}$-doped $\mathrm{TiO}_{2}$ nanofibers and its photocatalytic activity," Journal of Engineered Fibers and Fabrics, vol. 7, no. 3, pp. 16-20, 2012.

[44] L. Wen, B. Liu, X. Zhao, K. Nakata, T. Murakami, and A. Fujishima, "Synthesis, characterization, and photocatalysis of Fe-doped $\mathrm{TiO}_{2}$ : a combined experimental and theoretical study," International Journal of Photoenergy, vol. 2012, Article ID 368750, 10 pages, 2012.

[45] S. Agarwala, M. Kevin, A. S. W. Wong, C. K. N. Peh, V. Thavasi, and G. W. Ho, "Mesophase ordering of $\mathrm{TiO}_{2}$ film with high surface area and strong light harvesting for dye-sensitized solar cell," ACS Applied Materials and Interfaces, vol. 2, no. 7, pp. 18441850, 2010.

[46] J. Sirita, S. Phanichphant, and F. C. Meunier, "Quantitative analysis of adsorbate concentrations by diffuse reflectance FT-IR," Analytical Chemistry, vol. 79, no. 10, pp. 3912-3918, 2007.

[47] G. Wang, L. Xu, J. Zhang, T. Yin, and D. Han, "Enhanced photocatalytic activity of $\mathrm{TiO}_{2}$ powders (P25) via calcination treatment," International Journal of Photoenergy, vol. 2012, Article ID 265760, 9 pages, 2012.
[48] P. R. Mishra and O. N. Srivastava, "On the synthesis, characterization and photocatalytic applications of nanostructured $\mathrm{TiO}_{2}$," Bulletin of Materials Science, vol. 31, no. 3, pp. 545-550, 2008.

[49] M. K. Seery, R. George, P. Floris, and S. C. Pillai, "Silver doped titanium dioxide nanomaterials for enhanced visible light photocatalysis," Journal of Photochemistry and Photobiology A, vol. 189, no. 2-3, pp. 258-263, 2007.

[50] Z. Zhang, C.-C. Wang, R. Zakaria, and J. Y. Ying, "Role of particle size in nanocrystalline $\mathrm{TiO}_{2}$-based photocatalysts," Journal of Physical Chemistry B, vol. 102, no. 52, pp. 10871-10878, 1998.

[51] A. Olad, S. Behboudi, and A. A. Entezami, "Preparation, characterization and photocatalytic activity of $\mathrm{TiO}_{2} /$ polyaniline coreshell nanocomposite," Bulletin of Materials Science, vol. 35, no. 5, pp. 801-809, 2012.

[52] Y. Mizukoshi and N. Masahashi, "Photocatalytic activities and crystal structures of titanium dioxide by anodization: their dependence upon current density," Materials Transactions, vol. 51, no. 8, pp. 1443-1448, 2010.

[53] T. Yamashita and P. Hayes, "Analysis of XPS spectra of $\mathrm{Fe}^{2+}$ and $\mathrm{Fe}^{3+}$ ions in oxide materials," Applied Surface Science, vol. 254, no. 8, pp. 2441-2449, 2008.

[54] A. P. Grosvenor, B. A. Kobe, M. C. Biesinger, and N. S. McIntyre, "Investigation of multiplet splitting of Fe 2p XPS spectra and bonding in iron compounds," Surface and Interface Analysis, vol. 36, no. 12, pp. 1564-1574, 2004.

[55] G. K. Pradhan and K. M. Parida, "Fabrication of iron-cerium mixed oxide: an efficient photocatalyst for dye degradation," International Journal of Engineering Science and Technology, vol. 2, no. 9, pp. 53-65, 2010.

[56] A. Khare, R. J. Choudhary, K. Bapna, D. M. Phase, and S. P. Sanyal, "Resonance photoemission studies of (111) oriented $\mathrm{CeO}_{2}$ thin film grown on $\mathrm{Si}(100)$ substrate by pulsed laser deposition," Journal of Applied Physics, vol. 108, no. 10, Article ID 103712, 2010. 

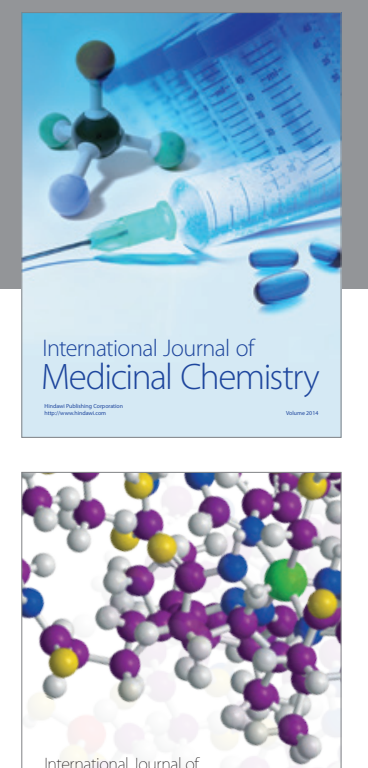

\section{Carbohydrate} Chemistry

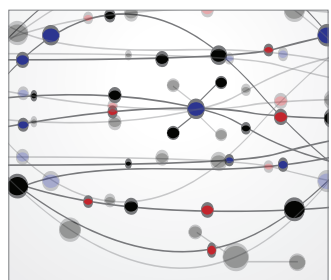

The Scientific World Journal
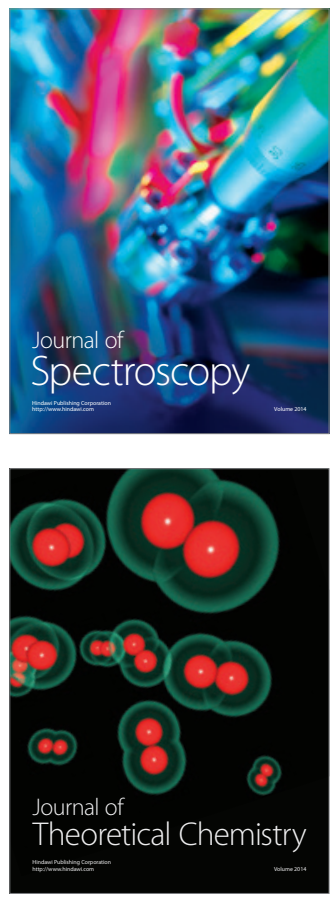
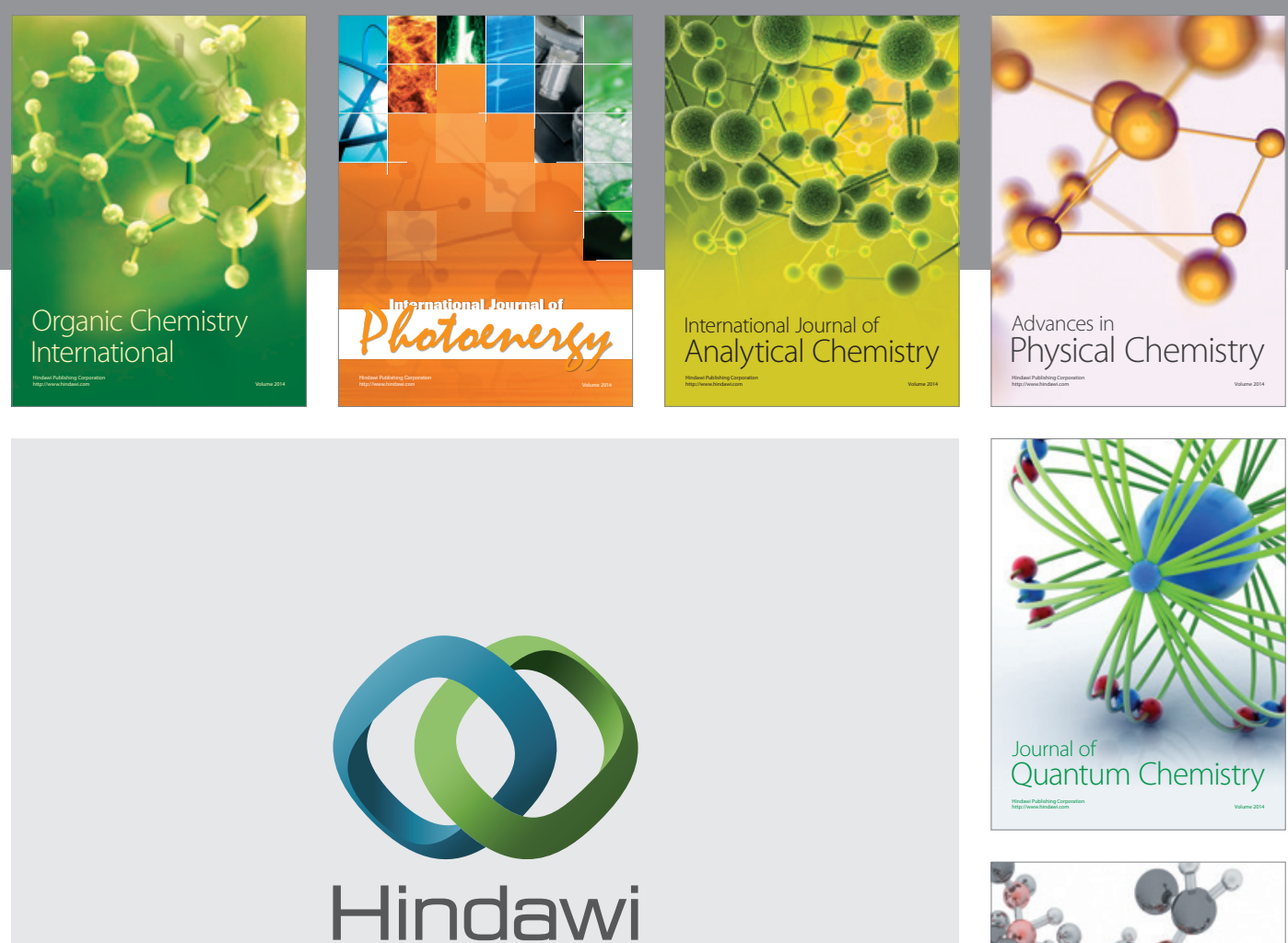

Submit your manuscripts at

http://www.hindawi.com

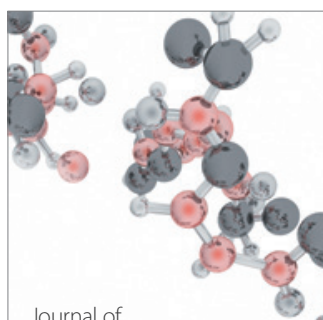

Analytical Methods

in Chemistry

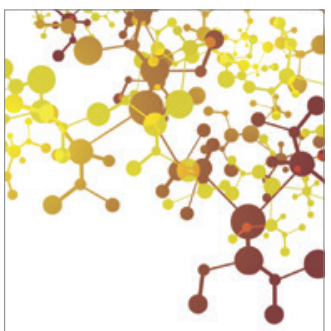

Journal of

Applied Chemistry

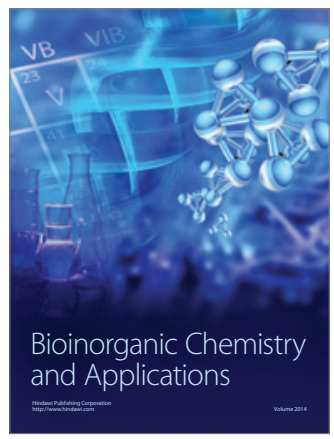

Inorganic Chemistry
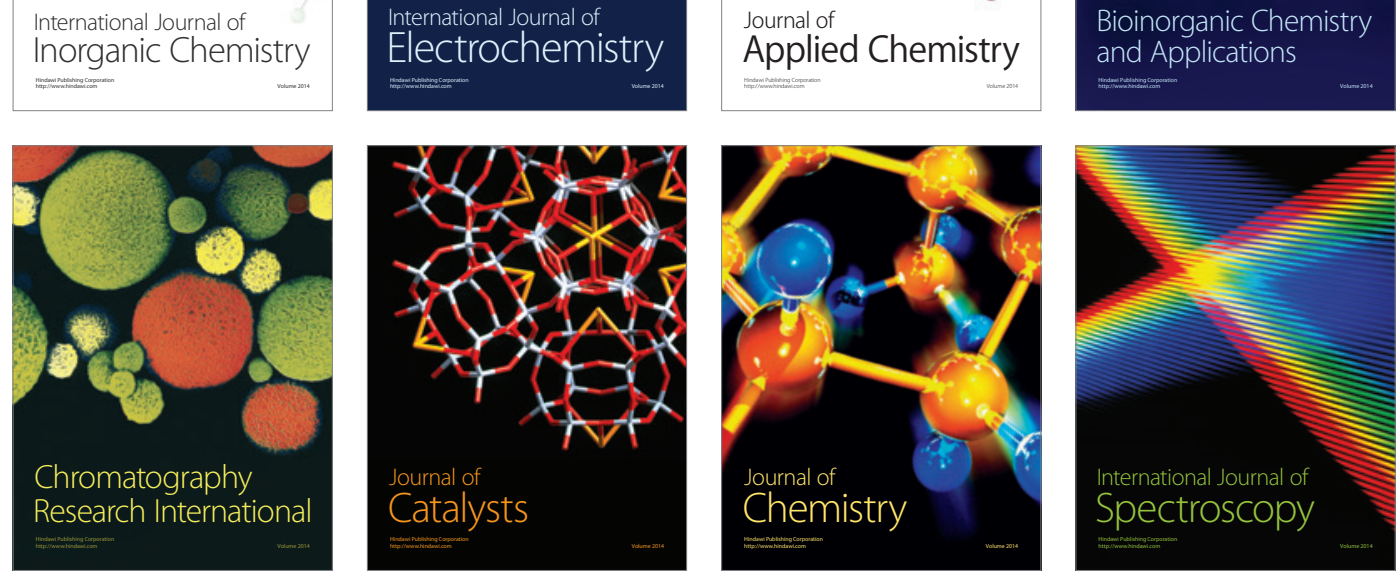